\title{
PERTIMBANGAN BERHUNI PADA PERMUKIMAN KAMPUNG DI KOTA MALANG
}

\author{
A. Farid Nazaruddin \\ Jurusan Teknik Arsitektur. Fakultas Sains dan Teknologi. Universitas Islam Negeri Maulana Malik Ibrahim \\ Malang. \\ Farid.nazaruddin@uin-malang.ac.id
}

\begin{abstract}
ABSTRAK
Permukiman kampung kota biasanya mempunyai reputasi yang tidak baik sebagai permukiman vernakular. Pandangan umum bahwa kampung kota itu miskin, tidak modern, tidak teratur. Sebagai tambahan, tidak dapat dimungkinkan memarkirkan kendaraan roda empat di dalam kampung karena jalan-jalan yang sempit. Dengan demikian seharusnya permukiman ini adalah permukiman yang dihindari, khususnya oleh orang yang mempu (golongan menengah keatas). Artikel ini membahas mengenai hasil penelitian terhadap mengapa orang orang yang mampu tersebut memutuskan untuk pindah atau menetap di permukiman kampung. Peneltian ini di lakukan pada rumah rumah yang mewah di kampung Kauman, Kampung Gandekan, Kampung Tongan, kampung Sawahan dan Kampung Arab di Kota Malang. Sampel dipilih berdasarkan penilaian peneliti terhadap kemewahan rumah dan bahwa rumah tersebut berada di jalan sempit kampung. Metode yang digunakan adalah wawancara mendalam untuk mengetahui pertimbangan pemilik pada setiap sampel. Penelitian ini menjunjukkan gambaran dasar terhadap faktor pertimbangan utama bertinggal di rumah mewah dalam kampung (meskipun mampu untuk berpindah keluar daerah kampung), adalah karena lingkungan dan suasana kampung itu sendiri.
\end{abstract}

Kata kunci: Kampung, permukiman, perspektif, pertimbangan, rumah mewah

\section{ABSTRACT}

City Kampung settlements usually unfavorable as a settlements, mostly by general perspective that kampung are "poor people" settlements, or not modern and not organized. In addition, it is not suitable to own a car and to be put in site (as would normally Indonesian people do), because of the really narrow streets in kampung. Thus, it should making them as settlements to be avoided. Especially by the so-called rich people. This Paper presents a result on preliminary research on those "rich" people about why one move or live in Kampung Settlements if they can afford to move away. The research conducted at all the expensive houses in Kampung Kauman, Kampung Gandekan, Kampung Tongan, kampung Sawahan and Kampung Arab in Malang City Indonesia. Samples are chosen by the researcher general assessments on its expensiveness and that the house is at the narrow streets of the Kampung. The Method used are in-depth interviews to know their considerations on each Samples. The Results that the basic factor for consideration on living in kampung settlements (even though they can afford to move away) is because of the atmosphere of Kampung neighborhood it self.

Keywords: Kampung, Settlements, Perspective, Considerations, expensive house, interviews 


\section{Pendahuluan}

Kampung kota umumnya memiliki bangunan relatif lebih padat, dan penduduknya bermata pencaharian di sektor informal, terbangun secara spontan sehingga sarana pelayanan perkotaan, seperti air bersih, sanitasi, dan drainase tidak memadai (UN Habitat, 2006). Kebersamaan, kekeluargaan, ikatan sosial budaya yang mengikat erat antara satu dengan yang lain telah terpatri kuat di kampung kota. Kebijaksanaan lokal dan kebijakan nusantara dapat kita temukan dengan mudah di dalam kampung kota (Pangarsa, 2006). Tentu akan sangat berbeda dengan rumah susun, perumahan dan apartemen. Kampung kota di kota kota besar di Indonesia biasanya adalah permukiman pusat kota yang timbul bahkan sebelum kota itu berdiri. Atau lebih tua dari kota tersebut (Nazaruddin, 2011).

Kampung pada masa lalu merupakan definitif dari desa. Saat ini kampung lebih disebut sebagai permukiman berenergi desa yang terletak di kota, atau desa yang terdapat di kota. (Funo, 2002). Kampung merupakan fitur unik yang terdapat di indonesia. Asal katanya kemungkinan berasal dari kata "compound". Kata bahasa Inggris yang terserap menjadi kata kampung yang mengindikasikan kompleks yang dihuni oleh etnis masyarakat yang sama di Batavia dan Melaka (Funo, 1985). Orang Inggris kemudian mulai menggunakan kata tersebut untuk mengindikasikan kelompok hunian yang seperti itu di India dan Afrika (Funo, 1991)

Secara umum terdapat anggapan bahwa kampung kota itu dipenuhi dengan masyarakat finansial menengah ke bawah, atau miskin, (Setiawan 2010) dihuni oleh masyarakat berpendidikan rendah (Winayati, 2004), juga dengan anggapan bahwa kampung kota itu kotor dan tidak sehat. Sedangkan perumahan adalah kawasan permukiman yang tertata, diisi oleh orang yang mampu di lingkungan yang bersih. Maka jika disuruh memilih antara kampung dan perumahan, tentu akan memilih perumahan.

Tetapi sepertinya hal itu tidak terjadi di beberapa kampung tua di kota Malang. Khususnya kampung-kampung tua, seperti Kauman, Tongan, dan kampung Arab. Dapat diamati dalam kampung-kampung itu keberadaan rumah-rumah mewah dengan luasan diatas $200 \mathrm{~m} 2$ yang seringkali bernilai milyaran, tumbuh dan terus bertambah-kembang. Banyak rumah-rumah di bongkar untuk dibangun rumah-rumah baru yang mewah.

Amatan awal, penulis melihat bahwa nilai materi rumah-rumah mewah itu sangat besar, antara 1-3 Milyar Rupiah. Dibangun pada 2-10 tahun terakhir. Jika dengan uang sebanyak itu, membangun atau membeli rumah di perumaham mewah akan dapat dilakukan dengan mudah. Akan mendapatkan fasilitas gaya hidup yang lengkap seperti taman, jalan lebar, ada tempat parkir, garasi mobil, satpam 24 jam, internet, TV Kabel, dan lain sebagainya. Seperti diketahui pada kampung-kampung tersebut, mobil didak dapat masuk ke dalam kampung.

Tetapi mengapa mereka memilih di dalam kampung kota? Sebuah pilihan yang seakan tidak masuk akal jika kita melihat tatanan pandangan masyarakat mayoritas tentang kampung kota yang kotor dan tidak teratur. Selain itu umumnya kampung mempunyai lebar jalan yang tidak dapat dimasuki oleh kendaraan roda empat dengan nyaman. Padahal secara akal, bagi orang yang mampu, mobil merupakan aset umum yang dimiliki. Rumah mewah dengan akses kendaraan yang sangat terbatas seakan menambah "siksaan" hidup di kampung kota. Dari pemahaman dasar tersebut, tercuat pertanyaan mengapa masyarakat memilih membangun rumah mewah mereka di kampung kota daripada perumahan.

Penelitiann terdahulu yang berhubungan dengan ini membahas mengenai pertimbangan konsumen dalam pembelian properti, Handayani, (2006) menyimpulkan mengenai faktor pertimbangan pembelian sebuah rumah yaitu faktor lokasi, faktor harga, faktor developer, spesifikasi bangunan dan fasiltias. Pada penelitian Anastasia, dkk 
(2005) faktor utama dalam pemilihan property adalah konsep developernya. Belum ada yang membahas untuk konteks rumah dalam kampung.

\section{Metode}

Teknik pengumpulan data yang digunakan dalam penelitian ini adalah (1) observasi, (2) pemotretan, dan (3) in depth interview dengan menggunakan openquisoner. Observasi langsung ke lapangan dilakukan dengan tujuan mengalami langsung objek arsitektur, sehingga memperoleh persepsi yang lebih akurat dan detail tentang objek arsitektur itu. Observasi dilakukan pada objek amatan lingkungan kampung dan rumah-rumah mewahnya. Teknik pemotretan juga dianggap memiliki akurasi yang tinggi, yang dapat memperkuat keandalan data. Pemotretan dilakukan setelah mendapatkan ijin pemilik rumah, sebagai data arsitektural objek amatan.

Kemudian in depth interview dengan open quisoner dilakukan oleh peneliti pada pemilik rumah. Wawancara diawali dengan menggali cerita mengenai sejarah rumah sepanjang penghuni mengingatnya, mengenai pemilik sebelumnya dan atau renovasi yang dilakukan. Kemudian pertanyaan mengarah kepada konteks perkampungan yang bertujuan untuk menggali pendapat mengenai rumahnya yang di dalam kampung. Mengapa dan bagaimana hidup di perkampungan padahal mempu untuk pindah. Pada akhirnya pertanyaan mengarah kepada konsep jika pemilik diberi pilihan untuk pindah ke tempat lain. Semua pertanyaan diberikan dengan open dan wawancara dilakukan secara santai sehingga pemilik rumah daapt terbuka dan banyak bercerita.

Pendekatan yang digunakan dalam penelitian ini adalah pendekatan rasionalistik kualitatif. Pendekatan ini menghasilkan data deskriptif berupa kata kata tertulis atau lisan dari para pelaku atau objek penelitian. Pendekatan diarahkan pada individu tersebut secara holistik/utuh. Metodologi rasionalistik menuntut spesifikasi variabel yang akan menjadi objek penelitian, yaitu sejarah rumah dan pertimbangan bertempat tinggal dari para pemilik rumah.

\subsection{Objek Penelitian}

Populasi Penelitian dilakukan di tiga kampung-kampung tua di Malang antara lain, Kampung Kauman, Kampung Gandekan, Kampung Tongan, kampung Sawahan dan Kampung Arab. Kampung kampung tersebut menurut penelitian awal, banyak berdiri rumah-rumah mewah di dalam kampung.

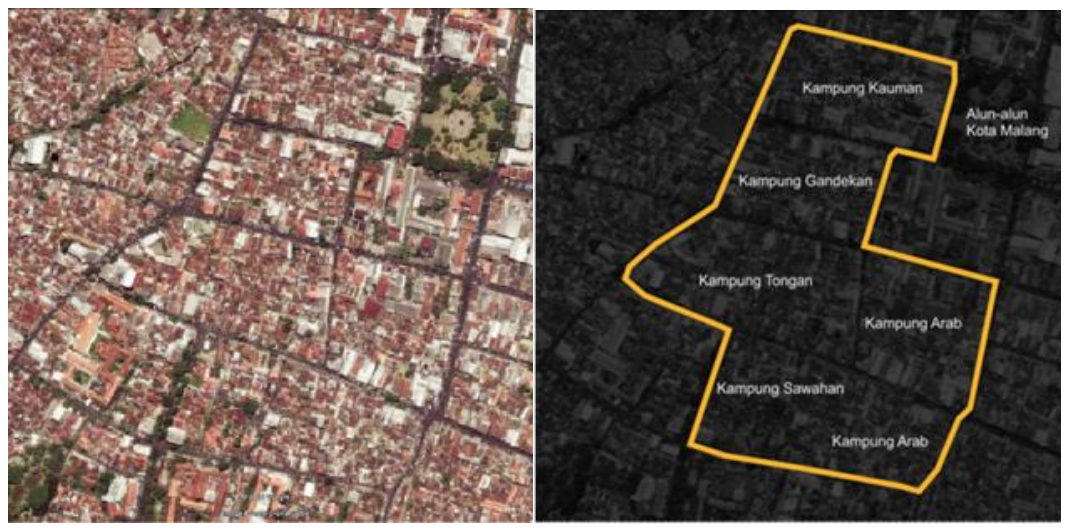

Gambar 1. Area Batasan Kawasan Penelitian 




Gambar 2. Lokasi Rumah Mewah

Secara detail, sampel penelitian adalah rumah-rumah mewah dalam kampungkampung tersebut. Penentuan sampel penelitian adalah mengidentifikasi unsur arsitektural dan ukuran luasan lantai dari rumah tersebut. Batasan ukuran luasan lantai sebagai penentu sampel penelitian untuk penelitian ini adalah rumah dengan minimal luasan $200 \mathrm{~m} 2$.

\subsection{Tahapan Penelitian}

1. Tahap awal penelitian.

Pengamatan dan survey awal dilakukan pada tahapan ini untuk memastikan rumusan masalah dan latar belakang penelitian. Pada tahapan ini, alat alat dan instrumen dipersiapkan, mendata dan mendiskripsikan objek penelitian di Tiga Kampung tersebut. Kemudian membuat daftar wawancara.

2. Tahap Pelaksanaan Penelitian

Pada tahapan ini, peneliti melakukan kuisoner/wawancara pada sampel penelitian. Kemudian menganalisa hasil quisoner/wawancara dengan kajian pustaka yang telah disusun. Selain itu juga melakukan pendataan arsitektural objek objek penelitian, mengolah hasil wawancara untuk digambarkan secara ruang apabila penelitian menunjukkan korelasi antara rumah tinggal dengan lingkungan tertentu.

3. Tahap akhir penelitian

Pada tahapan ini diharapkan kesimpulan dapat diambil yang mengarahkan pada temuan dan rekomendasi mengenai objek dan segala yang berhubungan dengannya.

\section{Hasil dan Diskusi}

Dari 70 populasi rumah mewah yang ada di kawasan penelitian, kemudian ditentukan sampel yang berdasar bahwa rumah mewah tersebut berada di jalan yang sempit dan tidak dapat dilewati kendaraan roda empat, menghasilkan 8 sampel sebagai objek penelitian.

\section{Rumah No. 1 dan 2}

Rumah 1 dan 2 ternyata dimiliki oleh keluarga yang sama. Sejarahnya adalah rumah 2 dibeli oleh keluarga bapak Jabli pada tahun 1977. Sebelumnya lebih banyak tanahnya daripada bangunan, karena total luas tanah adalah 1200 m2. Kemudian beliau 
merenovasi untuk menambah kamar dan ruangan di bagian belakang rumah. Sampai pada tahun 1990-an, keluarga Jabli bertotal 13 orang anggota keluarga yang tinggal di rumah ini.
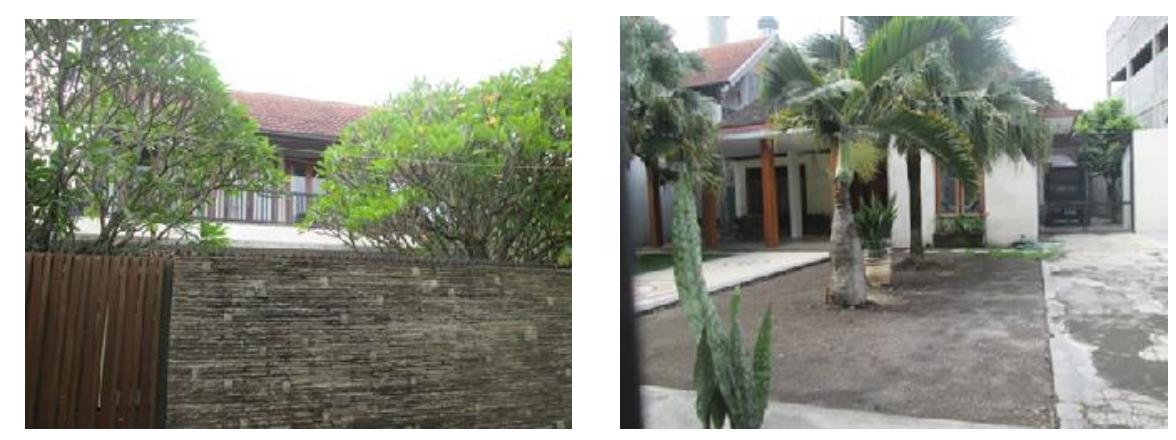

Gambar 3. Rumah No 1 dan No 2

Rumah ini mempunyai luasan lahan dan luasan rumah yang besar. Sampai mempunyai akses pintu khusus menuju area dalam Masjid Jami'.

Kemudian pada tahun 2000 tetangga rumah menjual rumahnya. Karena putra dan putri Bapak Ibu Jabli mulai menikah dan mempunyai keluarga sendiri, menjadikan kebutuhan akan rumah sendiri. Salah satunya adalah putranya. Rumah tetangga itu pun dibelinya. Dalam penelitian ini adalah rumah No 1.

Rumah ini dibeli seharga Rp. 500 Juta dan pada tahun 2003 dibongkar total untuk pembangunan rumah baru. Sehingga dapat dikatakan keluarga Jabli membeli tanah saja. Renovasi dilakukan dengan menggunakan bahan bangunan yang berharga mahal dan mewah, semua kayu di rumah ini memakai kayu jati tanpa mata (yang sekarang berharga $50 \mathrm{Juta} / \mathrm{m} 3$ ), dan granit untuk lantai. Peneliti mendapatkan informasi saat itu, bahwa renovasi menghabiskan dana Rp. 1,5 Milyar.

Setelah pembangunan rumah No 2 selesai, rumah No 1 direnovasi pada tampak depannya untuk memadukan kesan dengan bangunan rumah No 2 .

Pemilik sebelum tahun 1977 mempunyai rumah di daerah pasar besar kota Malang, dekat dengan pabrik. Karena alasan kesehatan, untuk menjauh dari polusi pabrik, Bapak Jabli menjual dan pindah ke rumah yang sekarang.

Keuntungan tinggal di perkampungan itu menurut Ibu Latifah, adalah sangat dekat dengan masjid, bahkan mempunyai akses langsung dengan masjid Jami Kota Malang. Selain itu dekat dengan sekolah anak-anak dan sekarang cucu. Dekat pula dengan tempat kerja, lingkungan yang aman karena tetangga saling menjaga, juga lingkungan yang tenang. Selain itu beliau menganggap perkampungannya bersih dan baik.

Keluarga jabli ternyata mempunyai beberapa Mobil, padahal akses ke dalam rumah sangat sulit. Inilah yang menjadi Kekurangan rumah, yaitu apabila ingin mengeluarkan atau memasukkan mobil harus dilakukan pelan pelan, karena jalan yang sempit, dan harus dilakukan subuh atau tengah malam. Karena banyaknya kegiatan, warung di jalan kampung.

Keluarga Jabli juga mempunyai beberapa rumah lain, yang ternyata juga berada di perkampungan. Tepatnya ada 3 rumah lain yang juga di perkampungan. Sekarang rumah lain itu ditinggali oleh putra putrinya. Sehingga saat ini rumah No 2, hanya ditinggali 4-5 anggota keluarga. Kamar kamar anaknya yang dahulu penuh sekarang jarang diisi. Hanya saat saat tertentu saja keluarga berkumpul di rumah ini.

Saat ditanyakan apabila ada yang ingin membeli rumah ini dengan harga mahal jauh diatas harga rumah, pemilik menolak untuk menjualnya. Dengan kesimpulan bahwa pemilik tidak akan berpindah atau menjual rumah ini dengan harga berapapun. 


\section{Rumah No. 3}

Pemilik rumah dan keluarganya adalah orang yang sebelumnya memang tinggal di perkampungan. Pada tahun 2006 beliau membeli rumah ini, pemilik tidak terbuka mengenai harga saat membeli rumah tersebut. Rumah tersebut kemudian dikontrakkan beberapa kali dan kemudian merenovasinya pada tahun 2011.

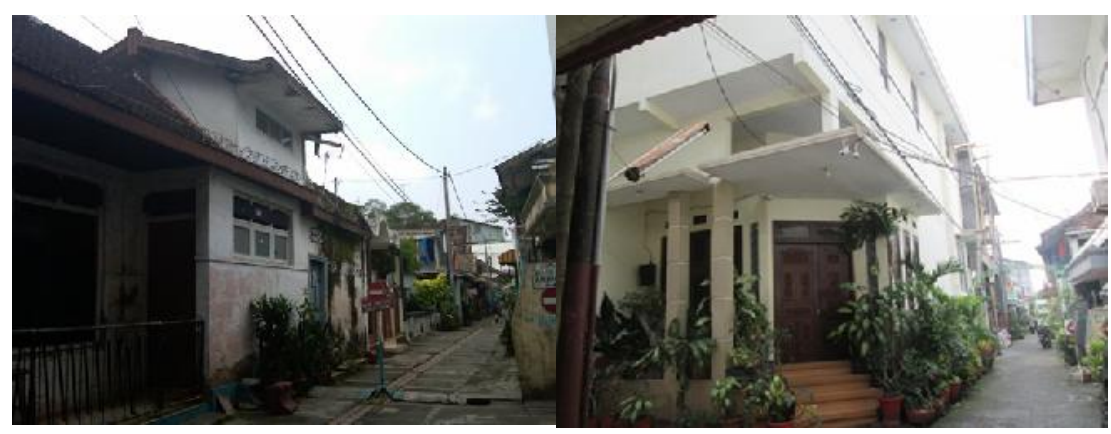

Gambar 4. Keadaan Rumah Sebelum dan Sesudah Di Renovasi

Renovasi tahun 2011 tersebut dilakukan secara total, yaitu dari rumah sebelumnya tidak ada yang dipertahankan. Dengan kata lain tinggal tanah saja (atau membeli tanah). Hal ini memberi nilai tambah pada objek penelitian, dimana pemilik rela membongkar (membuang) rumah lama. Perkiraan nilai rumah lama yang dibongkar adalah Rp. 100 Juta.

Melihat kualitas bahan bangunan dan luasan rumah peneliti memperkirakan Pembangunan rumah selesai dengan biaya Rp. 400 juta, yang terdiri dari 2 lantai rumah dan lantai ke 3 berupa area cuci dan jemuran yang cukup besar.

Keuntungan tinggal diperkalmpungan ini bagi pemilik adalah lingkungannya yang aman, nyaman dan sosialisasi antar tetangga yang sangat erat, yang tidak dapat ditemukan di perumahan. Selain itu, bagi bapak yudha, rumahnya jadi dekat dengan Masjid Jami'. Saat berada di rumah ini beliau memulai tradisi sabtuan, dimana setiap sabtu ada majelis ta'lim yang diadakan di rumahnya.

Kerugian tinggal di rumah ini adalah tempat parkir bagi mobilnya yang sulit. Hal ini karena mobil tidak dapat masuk ke dalam area perkampungan, menyebabkan mobil miliknya harus diparkir di pertokoan atau di luar area kampung yang jaraknya cukup jauh. Selain itu kesulitan air bersih PAM yang sering mati.

Rumah ini dihuni oleh empat orang anggota keluarga. Saat ditanya lebih lanjut, ternyata beliau mempunyai rumah lain di perkampungan, yang dipergunakan sebagai investasi, dan pemasukan tambahan, karena disewakan. Tetapi beliau sekeluarga memilih tinggal di rumah saat ini, karena memilih dekat dengan Masjid Jami'.

Beliau juga tidak akan pernah menjual rumah ini dengan harga yang mahal sekalipun. Beliau pun tidak mempunyai rencana atau cita-cita yang terbuka mengenai berpindah dari rumah ini, atau beliau rencananya menetap selamanya. "tidak bisa dibeli dengan uang" adalah kata kata beliau mengenai rumah dan lingkungannya. Beliau mengakui bahwa investasi yang dikucurkan pada rumah ini jauh lebih mahal daripada rumah di perumahan. Apalagi dengan berbagai kekurangan yang dialaminya. Air yang sering mati atau mobil yang kesulitan penyimpanannya.

Hal itu beliau maklumi, karena menurut pandangan beliau, beliau berani membayar berapapun untuk "membeli lingkungan". Karena membeli rumah tidak hanya membeli bentukan bangunan, tetapi juga orang-orang disekelilingnya. 


\section{Rumah No. 4}

Bapak Udin sebelumnya membeli rumah sederhana di kampung Kauman pada tahun 2013. Rumah pertama ini kecil dalam ukuran, yaitu kurang lebih $40 \mathrm{~m} 2$. Selama hampir satu tahun, beliau tinggal bersama keluarga di rumah kecil ini. Rumah ini dibeli dengan harga \pm Rp. 80 juta. Kemudian beliau renovasi menghabiskan dana \pm Rp. 50 Juta. Renovasi dilakukan dengan memperbaharui keramik, kusen, menambah ruangan dan pagar.

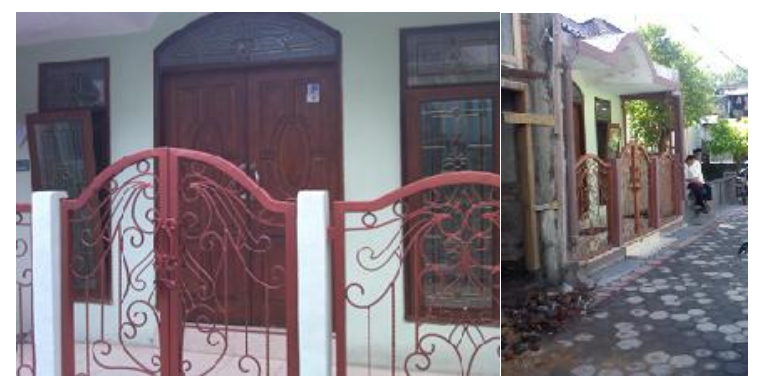

Gambar 5. Rumah yang pertama di beli oleh Bapak Udin.

Kemudian setelah setahun tinggal di tempat ini, tetangga beliau menjual rumah yang ditinggali seharga Rp. 700 Juta. Bapak Udin pun membelinya. Rumah tersebut sebelumnya bergaya kolonial belanda, dengan fitur arsitektural yang kuno. Bapak Udin memnutuskan untuk merombak total rumah tersebut dan tidak menggunakan fitur rumah lama sama sekali, atau dengan kata lain rumah tersebut di bongkar total. Perkiraan nilai bangunan tersebut adalah Rp. 100 juta. Dengan demikian, secara singkat, bapak udin membeli "tanah saja" seharga Rp. 800 Juta. Luas tanah adalah 154 m2.

Pembangunan rumah baru diatas tanah rumah lama dilakukan dari tahun 2015 dan sampai saat wawancara dilakukan, rumah baru masih dalam tahapan finishing. Rumah baru beliau bangun seluas $\pm 350 \mathrm{~m} 2$ yang dibangun 3 lantai + lantai jemuran. Melihat fitur struktur dan finishing bangunan, penulis memeperkirakan bahwa harga rumah baru adalah Rp. 600 Juta.

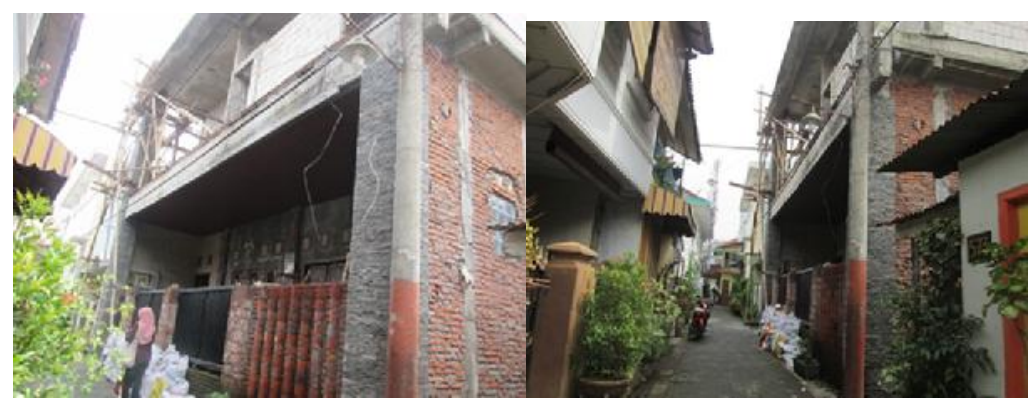

Gambar 6. Rumah Bapak Udin Saat Wawancara Dilakukan

Rumah pertama yang beliau huni pun langsung dihubungkan dengan rumah yang sedang dibangun ini. Meskipun belum selesai sepenuhnya, rumah ini sudah dipakai untuk beliau mempersiapkan masakan untuk bisnis warungnya.

Beliau merasakan berbagai keuntungan tinggal di area perkampungan ini, yaitu dekat dengan masjid, dekat dengan tempat kerjanya dan lingkungan yang nyaman. Karena letaknya yang di pusat kota Malang, dianggap dekat dengan seluruh bagian kota. Tetangga yang ramah juga menjadi daya tarik beliau. Lingkungan pun dianggapnya sebagai lingkungan yang aman.

Sedangkan kekurangannya adalah air PAM yang sering macet dan area parkir mobilnya yang tidak ada. kalaupun ada, parkir untuk menyimpan mobilnya dilakukan di 
tempat persewaan yang jauh dari lingkungan perkampungan. Khusus untuk area parkir mobil yang tidak ada pun menjadi nilai tambah bagi objek sampel ini bagi penelitian, karena demi tinggal di area perkampungan, Bapak udin dan keluarganya memutuskan untuk menjual mobilnya.

Saat diajukan untuk nantinya rumah itu dibeli oleh orang lain dengan harga yang pantas, bapak Udin menjawab tidak ingin menjualnya, juga tidak akan berpindah lagi. Karena banyaknya keuntungan untuk tinggal di perkampungan itu.

\section{Rumah No. 14}

Bapak husein adalah warga perkampungan ini sejak tahun 1986. Rumah ini sebelumnya adalah milik orangtuanya. Pada tahun 2009 beliau menikah dan kemudian merenovasi rumahnya menjadi seperti sekarang. Renovasi dilakukan dengan mempertahankan beberapa bagian dari rumah yang lama.

Melihat fasilitas arsitektural yang ada di rumah ini, antara lain, dinding, ornamen, keramik, kusen dan pintu, maka peneliti memperkiraan harga bangunan ini adalah Rp. 400 juta. Tidak termasuk harga tanah.

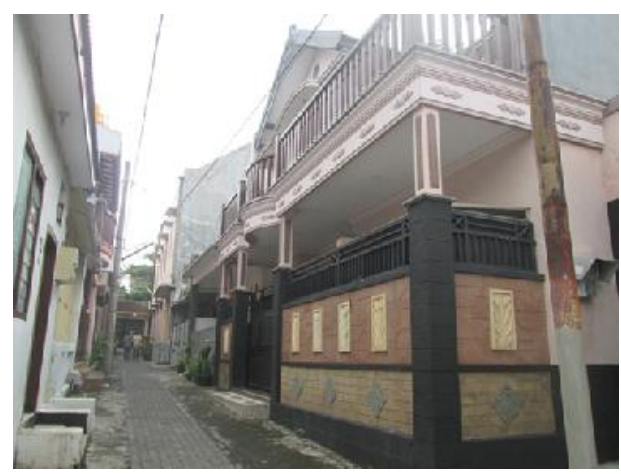

Gambar 7. Rumah Bapak Husein

Keuntungan tinggal di lingkungan rumah ini bagi Bapak Husein adalah tenang, strategis dan tidak banyak "acara". Bapak Husein saat diwawancara terkesan kaku dan serius, sehingga peneliti memperkirakan makna ganda terhadap kata "acara" yang dikatakan beliau. Yaitu acara dalam konteks acara lingkungan dan acara dalam konteks konflik dengan tetangga. Selain itu, keuntungan lain adalah dekat dengan masjid, dekat dengan pusat perbelanjaan (pusat kota), dekat dengan tempat kerja beliau, tenang, nyaman dan para tetangga yang ramah.

Kekurangan tinggal di rumah ini adalah area parkir mobil yang cukup jauh dari rumah. Yaitu diparkirkan di ruko di jalan Tongan. Sehingga saat Bapak Husein membutuhkan kendaraannya, beliau harus jalan kurang lebih 5 menit untuk mengambilnya. Tetapi bagi beliau, jarak itu masih dianggap cukup dekat.

Rumah ini dihuni oleh beliau, istri dan ibu. Rumah ini tidak akan dijual oleh Bapak Husein berapapun harganya. Beliau tidak berencana pindah dari rumah ini sampai kapanpun.

\section{Rumah No. 21}

Rumah Bapak Umar Assegaf adalah rumah yang dimilikinya secara turun temurun, dimana beliau dari lahir sudah tinggal di rumah ini. Tahun 2011 rumah ini direnovasi bagian tampak depannya saja, sedangkan pada bagian dalam hanya perawatan sedikit. Tidak ada penambahan ukuran rumah sebelumnya. 


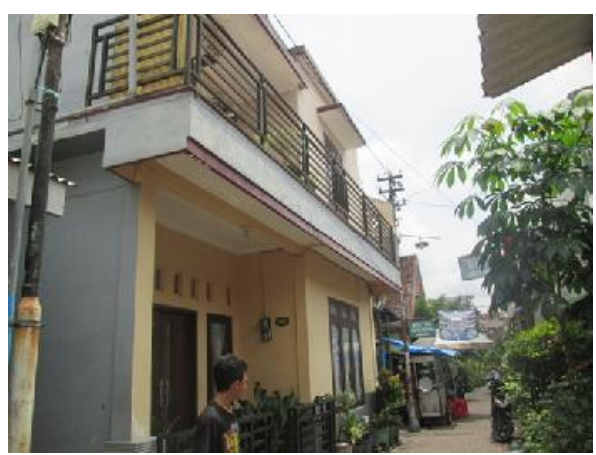

Gambar 8. Rumah Bapak Umar Assegaf

Uniknya rumah ini dulunya dihuni oleh 13 orang anggota keluarga Assegaf. Orang tua beliau dan 11 anaknya. Sejalan dengan waktu, ke 11 orang itu mulai berkeluarga dan memiliki rumah sendiri. Sedangkan Bapah Umar Assegaf sebelumnya memang tinggal di rumah ini beserta anak istri, tetapi sejak anaknya sudah berkeluarga, dan istri beliau meniggal dunia, beliau memilih untuk tinggal bersama keluarga anaknya di rumah lain. Sehingga rumah ini menjadi rumah tinggal yang seringkali kosong. Hanya pada saat weekend beliau beserta keluarganya juga kakak dan adiknya berada di rumah ini. Dengan kata lain eumah ini sekarang berfungsi sebagai rumah singgah keluarga.

Keuntungan tinggal di rumah ini bagi Bapak Umar adalah karena peninggalan orang tua, beliau juga merasa nyaman dan terbiasa sejak kecil di rumah ini. Selain itu, tetangga yang baik dan lingkungan yang tenang. Tetapi karena sekarang beliau sendiri sejak istrinya meninggal, maka beliau dengan berat hati memilih tinggal bersama anaknya. Setelah peneliti telusuri, ternyata rumah anaknya juga di dalam kampung, dan letaknya tidak terlalu jauh dari rumah ini, yaitu di sukun dan kampung sawahan.

Karena nilainya bagi Bapak Umar, rumah ini pun tidak akan pernah dijual dengan harga berapapun, karena bagi dia kenangan dan fungsi kumpul keluarga di rumah orang tua sangat penting dan tidak ternilai.

\section{Rumah No. 22}

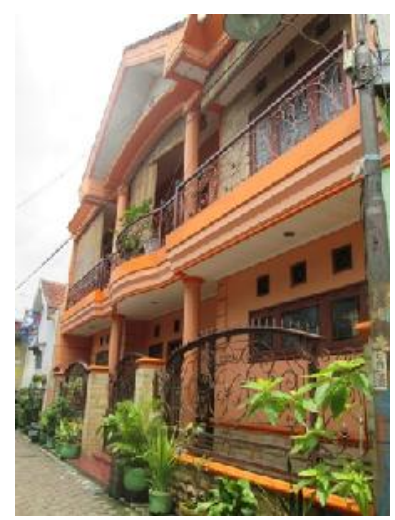

Gambar 9. Rumah Ibu Sa'diah Marfadia

Pemilik saat diwawancarai terkesan terburu-buru dan sedang siap-siap untuk pergi. Rumah ini adalah rumah asli milik orang tua beliau. Sudah 50 tahun beliau tinggal di rumah ini. Rumah ini terakhir direnovasi 15 tahun yang lalu. Rumah ini dihuni oleh 6 anggota keluarga beliau.

Peneliti bertanya beberapa pertanyaan dan beliau menjawab dengan terburuburu beberapa pertanyaan saja, sedangkan yang lain tidak terjawab. Tetapi ada kesan 
besar beliau tinggal di perkampungan, yaitu bahwa di perkampungan mempunyai tetangga yang akrab dan hubungan antar tetangga yang lebih erat.

\section{Rumah No. 27}

Pemilik adalah penghuni baru yang pindah ke rumah ini tahun 2010. Rumah ini dibeli pemilik tahun 2009 kemudian Rumah ini direnovasi tahun 2009 lalu dengan renovasi perumahan tampak depan rumah dan beberapa fitur arsitektural lain.

Dari luasan rumah yang $\pm 300 \mathrm{~m} 2$ rumah ini dihuni oleh hanya 2 orang saja, yaitu ibu Wardah dan suaminya, yang keduanya berusia \pm 70 tahun. Sedangkan putra putrinya tidak tinggal di rumah ini. Diperkirakan oleh peneliti, rumah ini bernilai Rp. 500 juta

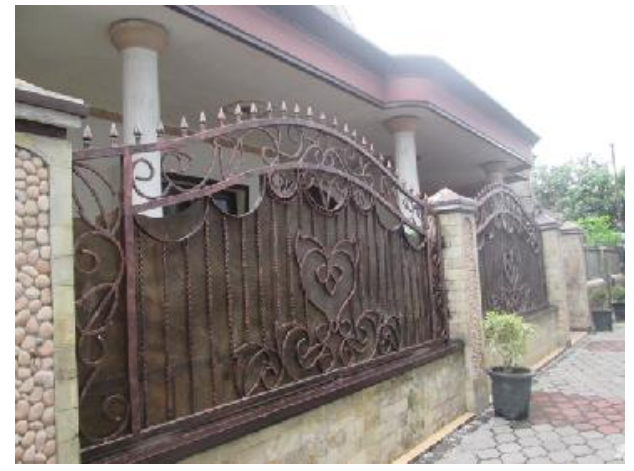

Gambar 10. Rumah Bapak Alibafana

Keuntungan berada di perkampungan ini menurut pemilik rumah adalah kenyamanan dan merasa sudah betah. Mereka merasa sangat bahagia tinggal di rumah ini. Lingkungan yang baik dan bersih. Sedang, Kekurangannya adalah kadang terlalu banyak kegiatan yang terlalu menguras tenaga. Bagi lansia, kegiatan ibu-ibu kadangkala terlalu melelahkan untuk diikuti.

Beliau juga memiliki rumah yang lain sebagai investasi yang disewakan, dan rumah tersebut ada di daerah perkampungan juga. Keluarga lansia ini tidak mempunyai kendaraan roda empat.

Saat diajukan juka ada yang ingin membeli rumahnya dengan harga tinggi, mereka dengan yakin memilih tidak akan menjualnya. "Tidak mungkin" kata mereka.

\subsection{Analisa}

Dari sejarah rumah objek teliti, ternyata beberapa rumah mewah yang ada di daerah Kampung Kauman, Kampung Gandekan, Kampung Tongan, kampung Sawahan dan Kampung Arab, adalah rumah dengan pemilik yang bergenerasi dan turun temurun (kepemilikan dengan warisan). Atau dengan kata lain pemilik sebelumnya adalah orang tua mereka. Yaitu, pada rumah Bapak Husein (rumah No 14), rumah Bapak Assegaf (rumah No 21), rumah Ibu Sa'diah (rumah No 22).

Meskipun merupakan rumah warisan orang tua mereka, rumah dalam perkampungan itu mereka renovasi dan tinggali. Tidak ada keinginan mereka ingin menjualnya. Mereka semua merasa sangat nyaman tinggal di dalam perkampungan kota, meski beberapa kendala mereka hadapi, seperti sulitnya air dan parkir kendaraan roda empat yang tidak tersedia.

Temuan penelitian pada rumah yang dibeli atau bukan hasil warisan terlihat pada kasus per kasus yang menarik ditelaah lebih lanjut. Seperti Pada rumah Ibu Latifah Jabli (rumah 1 dan 2), rumah dengan luasan lahan yang sangat besar, tetapi keluarganya seakan tidak mau lepas dari wilayah perkampungan kota berbagai investasi properti 
yang dilakukan adalah membeli dan merenovasi rumah rumah yang ada di perkampungan. Pembelian dan renovasi pun dilakukan dengan biaya yang setara dengan rumah mewah dalam perumahan yang mewah pula.

Pada rumah Bapak Yudha (rumah No 3), dan rumah Bapak Udin (rumah No 4) adalah pemilik rumah yang berpindah dengan membeli rumah di dalam kampung kota dan merenovasi rumahnya dengan biaya yang tidak sedikit. Keduanya memilih berpindah dalam kampung Kauman untuk dekat dengan Masjid Jami'. Meski beberapa kendala dihadapi tetapi tetap tidak ingin berpindah dari perkampungan ini.

Khusus untuk Bapak Udin dan keluarganya memang bercita cita untuk berpindah di dalam kampung Kauman karena memang kampung tersebut terkenal dengan unsur religi yang kuat. Renovasi rumahnya pun sampai menyentuh angka Milyar, yang setara dengan harga rumah di perumahan mewah. Bahkan Bapak Udin rela menjual kendaraan roda empatnya untuk tinggal di perkampungan daripada ribet untuk memparkirkannya karena tidak ada tempatnya (tidak bisa masuk). Dengan demikian keluarga Bapak Udin rela merubah pola hidup yang terbiasa memakai kendaraan roda empat demi tinggal di perkampungan.

Semua penghuni baru membeli rumah lama dan merombak total rumah lama untuk menjadi rumah baru. Semua responden beragama Islam.

Dari faktor pertimbangan, semua responden mengaku kalau pertimbangan utama dalam memutuskan untuk tinggal di perkampungan adalah faktor kemasyarakatan kampung yang akrab dan lingkungan yang baik.

\section{Simpulan}

Penelitian ini menjunjukkan gambaran dasar terhadap faktor pertimbangan utama untuk tinggal di rumah mewah dalam kampung (meskipun mampu untuk berpindah keluar daerah kampung) adalah karena lingkungan dan suasana kampung itu sendiri. Semua responden menjelaskan bahwa kehidupan di dalam lingkungan kampung yang baik menjadi dasar kuat faktor pertimbangan, secara khusus adalah perilaku akrab bertetangga.

Semua rumah responden direnovasi menjadi rumah mewah. Kerelaan untuk merenovasi rumah kampung yang awalnya sederhana menjadi rumah mewah dengan biaya besar, menunjukkan nilai pentingnya tinggal di perkampungan bagi mereka.

Semua responden menekankan bahwa rumah mereka tidak akan dijual dengan harga yang lebih sekalipun. Mereka pun tidak ada rencana untuk berpindah dari perkampungan.

Anggapan bahwa perkampungan hanya untuk warga kalangan menengah kebawah, dan warga akan berpindah ke daerah yang lebih tertata (baca:perumahan) apabila telah mampu tidak terbukti. Bahkan terdapat kecenderungan perpindahan dilakukan dari perumahan ke perkampungan karena melihat nilai nilai lokal yang ada di perkampungan, khsusunya hubungan antar tetangga yang baik.

Perinsip Islam dianut semua responden dalam memilih lingkungan dan tetangga yang baik dalam pertimbangan lingkungan rumah mereka Sesuai dengan anjuran Nabi Muhammad SAW dalam HR Ahmad, al-Hakim dan al-Bukhari.

Hadits itu menjelaskan bahwa memilih tempat tinggal yang baik bukan hanya bertujuan untuk kenyamanan diri dan anggota keluarga semata, ataupun gaya hidup saja, tapi lebih dari itu. Untuk mengusahakan lingkungan pergaulan yang baik bagi anggota kelurga, terutama anak-anak yang sangat mudah terpengaruh dan mengikuti apapun yang biasa mereka saksikan di lingkungan tempat tinggal mereka. 
Dengan demikian, perspektif dalam melihat perkampungan kota yang kurang baik seharusnya diarahkan menuju perspektif yang fokus kepada kebijaksanaan lokal yang ada di dalamnya, yang patut untuk dipertahankan dan dikembangkan.

\section{Daftar Pustaka}

Anastasia, Njo dkk. 2005. Analisa Faktor-Faktor Yang Dipertimbangkan Konsumen Dalam Pembelian Properti Di Citraraya Surabaya. Civil Engineering Dimension, Vol. 7, No. 2, 75 - 80, September 2005. ISSN 1410-9530

Funo, Shuji. 1991. Studies of Transitional Process of Kampung and Kampung Housing System - Considerations on Alternative Strategies for Housing. Doctorate Dissertation (Tokyo University), 1987, The Prize of Architectural Institute of Japan for Research Thesis.

Funo, Shuji. Et.all. 2002. Typology of Kampung Houses and Their Transformation Process A Study on Urban Tissues of an Indonesian City. Journal of Asian Architecture and Building Engineering

M. Handayani Butar Butar. 2006. Analisis Faktor-Faktor Yang Dipertimbangkan Konsumen Dalam Pembelian Properti Di Yogyakarta. S2 thesis, Universitas Atma Jaya Yogyakarta.

Pangarsa, Galih Widjil. 2006. Merah Putih Arsitektur Nusantara. Andi Offset. Yogyakarta.

Setiawan, Bakti. 2010. Kampung Kota dan Kota Kampung: Tantangan Perencanaan Kota di Indonesia. Pidato Pengukuhan Jabatan Guru Besar dalam Ilmu Perencanaan Kota. Yogyakarta. 28 Oktober 2010.

UN Habitat. 2006. Laporan Kelompok Keahlian Perumahan dan Permukiman: Transformasi Permukiman Pasca Tsunami di Aceh. Institut Teknologi Bandung-UN Habitat.

Winayati, Lana. C. Lang, Heracles. 2004. Provision of urban services in an informal settlement: a case study of Kampung Penas Tanggul, Jakarta. Habitat International. Volume 28, Issue 1, March 2004, Pages 41-65 